\title{
Pentingnya Implementasi Budaya Keselamatan Pasien Oleh Perawat di Rumah Sakit
}

\author{
Nikita Gina Chesena Sembiring \\ nikitagina.ng@gmail.com
}

\section{LATAR BELAKANG}

Keselamatan pasien merupakan isu global yang paling penting saat ini di mana sekarang banyak dilaporkan tuntutan pasien atas medical error yang terjadi pada pasien. Keselamatan pasien Rumah Sakit adalah suatu sistem dimana Rumah Sakit membuat asuhan pasien lebih aman yang memiliki asesmen risiko, identifikasi dan pengelolaan hal yang berhubungan dengan risiko pasien, pelaporan dan analisis insiden, kemampuan belajar dari insiden dan tindak lanjut (Kemenkes RI 2011).

Pelayanan keperawatan adalah pelayanan profesional yang dilakukan secara holistik mencakup pelayanan biologis, psikologis, sosiologis, dan spiritual yang mengacu pada standar profesional keperawatan dan menggunakan etika keperawatan sebagai tuntutan utama (Nursalam,2011). Pelayanan yang dilakukan perawat sangat penting karena perawat sebagai bagian integral dari tenaga kesehatan di Rumah Sakit, merupakan tenaga kesehatan yang paling lama dan paling dekat dengan pasien. Maka perawat mempunyai peran yang sangat penting dalam memberikan pelayanan secara menyeluruh atau holistik. Namun, dalam kenyataannya pelayanan keperawatan secara menyeluruh belum terlaksana secara optimal terutama pada pasien dengan penyakit kronis atau pasien yang mengalami masalah psikologis.

Pelayanan keperawatan secara holistik perlu dilakukan untuk meningkatkan kualitas pelayanan dan kepuasan pasien. Kualitas pelayanan sangat menentukan kepuasan pasien, sebagaimana hasil penelitian yang dilakukan oleh Susi Andriani dan Sunarto 2009 menunjukkan bahwa kualitas pelayanan mempunyai hubungan yang positif dan signifikan dengan tingkat kepuasan pasien rawat inap di Rumah Sakit. Kepuasan dan keselamatan pasien dengan tata kelola klinis serta efisiensi merupakan hal penting dalam menjamin kualitas pelayanan kesehatan (Boy, 2007).

Isu tentang keselamatan pasien mendapat perhatian pemerintah seperti yang dituangkan dalam undang-undang Kesehatan Nomor 36 tahun 2009 dan undang-undang 
Rumah Sakit nomor 44 tahun 2009, bahwa Rumah Sakit wajib melaksanakan pelayanan kesehatan yang aman bermutu anti diskriminasi dan efektif dengan mengutamakan kepentingan pasien.

Rumah Sakit wajib memenuhi hak pasien memperoleh keamanan dan keselamatan selama dalam perawatan di rumah sakit. Kepuasan merupakan bentuk perasaan seseorang setelah mendapatkan pengamalan terhadap kinerja pelayanan yang telah memenuhi harapan. Kepuasan yang ditunjukkan oleh pasien karena ketersediaan sarana prasarana yang memadai selain kualitas pelayanan yang ditunjukkan dengan pelayanan yang ramah dan sopan, kebersihan, kerapian kenyamanan dan keamanan ruangan serta kelengkapan, kesiapan dan kebersihan peralatan medis dan non medis.

Keselamatan pasien adalah suatu sistem dimana rumah sakit membuat asuhan pasien lebih aman dalam upaya mencegah terjadinya cedera yang disebabkan oleh kesalahan akibat melaksanakan suatu tindakan atau tidak mengambil tindakan yang seharusnya diambil. Berdasarkan Peraturan Menteri Kesehatan Republik Indonesia Nomor 11 tahun 2017, keselamatan pasien merupakan suatu sistem yang membuat asuhan pasien lebih aman, meliputi asesmen risiko, identifikasi dan pengelolaan risiko pada pasien, pelaporan dan analisis insiden, kemampuan belajar dari insiden dan tindak lanjutnya, serta implementasi solusi untuk meminimalkan timbulnya risiko dan juga mencegah terjadinya cedera yang disebabkan kesalahan akibat melaksanakan suatu tindakan atau tidak mengambil tindakan yang seharusnya diambil.

Salah satu tujuan dari keselamatan pasien adalah mengurangi angka insiden keselamatan pasien (IKP). Insiden keselamatan pasien adalah setiap kejadian yang tidak disengaja dan kondisi yang mengakibatkan cedera yang dapat dicegah pada pasien. IKP terdiri dari kejadian tidak diharapkan (KTD), kejadian nyaris cedera (KNC), kejadian tidak cedera (KTC), kejadian potensial cedera (KPC), dan sentinel (Gunawan, Widodo \& Harijanto,2015).

Perawat adalah pejabat eksekutif kesehatan dengan waktu kerja tertinggi yang memberikan 24 jam pelayanan terus-menerus serta harus berkolaborasi dengan tim kesehatan lain dan oleh karena itu itu hal tersebut dapat menyebabkan atau berisikan terjadinya insiden keselamatan pasien. Perawat dalam mengimplementasikan asuhan keperawatan dan mewujudkan keselamatan pasien di rumah sakit dapat dirumuskan sebagai berikut : perawat harus mematuhi standar pelayanan dan SOP yang telah ditetapkan, menerapkan prinsip etik 
dalam memberikan asuhan keperawatan, memberikan pendidikan kepada pasien dan keluarga pasien tentang asuhan keperawatan yang sedang dijalankan, selalu bekerjasama dengan tim kesehatan yang lainnya dalam memberikan asuhan keperawatan, menerapkan komunikasi yang baik terhadap sejawat, pasien dan keluarga, selalu proaktif dan peka dalam setiap menyelesaikan kejadian atau insiden yang berkaitan dengan keselamatan pasien, mendokumentasikan segala bentuk kegiatan yang ada hubungannya dengan asuhan keperawatan yang dilakukan kepada pasien.

Budaya keselamatan pasien merupakan suatu hal yang penting karena membangun budaya keselamatan pasien merupakan suatu cara untuk membangun program keselamatan pasien secara keseluruhan, karena apabila kita lebih fokus pada budaya keselamatan pasien maka akan lebih menghasilkan hasil keselamatan yang lebih apabila dibandingkan hanya memfokuskan pada programnya saja. Budaya keselamatan pasien adalah bagian dari kesalahan laten yang terkait dengan manajemen, sedangkan indikator budaya keselamatan meliputi kerjasama, komunikasi, kepemimpinan, pelaporan dan respon terhadap kesalahan tidak menghukum.

\section{METODE}

Kajian ini dilakukan dengan metode menganalisis dari berbagai sumber bacaan. Baik dari berbagai jurnal online, e-book, skripsi yang memiliki hubungan dengan budaya keselamatan pasien.

Penulisan kajian ini melakukan metode perbandingan antar satu artikel dengan artikel lainnya. Kemudian perbandingannya ditulis secara beraturan dalam hasil dari kajian. Dengan isi yang akan dibandingkan tetap berhubungan dengan budaya keselamatan pasien.

\section{HASIL}

Penelitian Pham. JC et al (2016) dilakukan di 11 rumah sakit dari 5 negara terdapat 52 insiden patient safety yaitu Hongkong 31\%, Australia 25\%, India 23\%, Amerika 12\% dan Kanada 10\%. Sementara di Brasil kejadian adverse event di rumah sakit diperkirakan 7,6\% (Duarte, Euzébia, \& Santos, 2017). Dari beberapa hasil penelitian ini bahwa insiden keselamatan pasien masih banyak di temukan di berbagai negara di dunia. 
Berdasarkan data hasil penelitian terkait keselamatan pasien di Indonesia yang telah dilakukan oleh Nurmalia \& Nivalinda (2016) pada rumah sakit pemerintah di Semarang bahwa sebesar 56,2\% mentoring pelaksanaan keselamatan pasien masih kurang baik, sementara di rumah sakit swasta panti waluya sawahan Malang oleh Harus B.D (2015) dilaporkan data Kejadian Tidak Diharapkan (KTD) 9 insiden (41\%), Kejadian Nyaris Cendera (KNC) 6 insiden (27\%), Kejadian Potensial Cedera (KPC) 5 insiden (23\%), Kejadian Tidak Cedera (KTC) 2 insiden (9\%). Data insiden keselamatan pasien masih banyak ditemukan baik di rumah sakit pemerintah maupun swasta meskipun telah lulus akreditasi, sehingga dapat menimbulkan dampak negatif terhadap pelayanan kesehatan.

Penelitian Swift (2017) di rumah sakit Amerika Serikat menemukan bahwa pasien yang mengalami peristiwa KTD mengakibatkan kerugian biaya sekitar $\$ 500.000$ atau diasuransikan sebesar \$1 juta per kesalahan. Penelitian oleh Gerven et al. (2016) bahwa sekitar $15 \%$ professional kesehatan mempertimbangkan untuk meninggalkan profesinya akibat kesalahan yang dilakukan. Professional kesehatan ini lebih cenderung dialami oleh pelayanan perawat.

Tahun 2000, Institute of Medicine, Amerika Serikat dalam “TO ERR IS HUMAN, Building a Safer Health System" melaporkan bahwa dalam pelayanan pasien rawat inap di rumah 1 Dosen Tetap FK-UKI sakit ada sekitar 3-16\% Kejadian Tidak Diharapkan (KTD/Adverse Event).

Insiden keselamatan pasien di Indonesia menurut provinsi pada tahun 2007 menemukan provinsi DKI Jakarta peringkat di antara yang tertinggi, 37,9\% lainnya provisi Jawa Tengah, 15,9\%, 13,8\% DI Yogyakarta, Jawa Timur 11,7\%, Sumatera Selatan 6,9\%, 2,8\% Barat Jawa, Bali 1,4\%, 10,7\% Aceh, Sulawesi Selatan 0,7\%.

Menurut hasil penelitian yang dilakukan Foster \& Rose dalam Yulia (2010) di UGD Rumah Sakit Pendidikan Otawa Kanada terhadap 399 pasien, didapatkan hasil Kejadian Tidak Diharapkan (KTD) sebanyak 24 kasus (6\%), Kejadian Tidak Diharapkan (KTD) dapat dicegah 17 kasus (71\%), Kejadian Tidak Diharapkan (KTD) tidak dapat dicegah 6 kasus (25\%), dan perpanjangan masa perawatan 15 kasus (62\%).

Laporan insiden keselamatan pasien di Indonesia oleh Komite Keselamatan Pasien Rumah Sakit Indonesia berdasarkan provinsi pada kuartal 1 periode Januari- April 2010 ditemukan provinsi Jawa Barat menempati urutan tertinggi sebesar 33,33\% diantara provinsi 
lainnya (Banten 20,0\%, Jawa Tengah 20,0\%, DKI Jakarta 16,67\%, Bali 6,67\%, Jawa Timur 3,37\%) (Komite Keselamatan Pasien RS, 2008).

Laporan Pengendalian Mutu dan Keselamatan Pasien (PMKP) Rumah Sakit Umum Daerah Provinsi Nusa Tenggara Barat tahun 2017 insiden keselamatan pasien masih terjadi di Rumah Sakit Umum Daerah Provinsi Nusa Tenggara Barat, diantaranya adalah Kejadian Nyaris Cidera (KNC) sebanyak 16 kasus (89\%) yang meliputi salah memberi resep sebanyak 2 kasus, salah membaca resep 2 kasus, salah memberikan obat sebanyak 7 kasus, obat expired date sebanyak 1 kasus, obat tertukar dengan pasien lain sebanyak 2 kasus dan salah menulis nama pada obat yang akan diberikan kepada pasien sebanyak 2 kasus, insiden keselamatan pasien yang masih terjadi satu lagi adalah Kejadian Potensi Cedera (KPC) sebanyak 2 kasus (11\%) yang kasusnya adalah air tumpah dari atap berwarna hitam sebanyak 1 kasus dan air tumpah dari plafon sebanyak 1 kasus. Dan untuk insiden keselamatan pasien lainnya seperti Kejadian Tidak Cedera (KTC), Kejadian Tidak Diharapkan (KTD) dan Sentinel sudah masuk dalam kategori baik karena tidak ada kasus yang terjadi selama tahun 2017 kemarin (Profil RS, 2018)

Di Eropa pasien dengan risiko infeksi 83,5\% dan bukti kesalahan medis menunjukkan 50-72,3\%. Di kumpulkan angka-angka penelitian rumah sakit di berbagai Negara, ditemukan KTD dengan rentang 3,2-16,6 \% (WHO, 2014 ; (Lombogia, 2016).

Menurut JCAHO (2007),65 \% dari KTD yang terjadi di rumah sakit berdampak pada kematian pasien. Menurut KKP-RS (2010), insiden KTD di Indonesia mencapai 46,67\% dengan provinsi Jawa barat menempati urutan tertinggi yaitu 33.33\%, dan berurutan provisi Banten sebesar 20.0\%, Jawa Tengah sebesar 20.0\%, DKI Jakarta sebesar 16.67\%, Bali sebesar $6.67 \%$, dan Jawa Timur sebesar 3.33\% .

\section{PEMBAHASAN}

Keselamatan pasien adalah prinsip dasar dalam pelayanan kesehatan. Menurut Depkes RI (2008) Keselamatan Pasien (patient safety) rumah sakit adalah suatu sistem dimana rumah sakit membuat asuhan pasien lebih aman. Salah satu tujuan keselamatan pasien adalah menurunkan KTD yang merupakan bagian dari insiden keselamatan pasien. Untuk mencapai tujuan tersebut, maka disusunlah Sasaran Keselamatan Pasien yang bertujuan mendorong perbaikan spesifik dalam keselamatan pasien. Oleh karena itu, jika rumah sakit ingin 
menurunkan kejadian insiden keselamatan pasien maka rumah sakit harus menerapkan budaya keselamatan pasien. Sampai saat ini, banyak negara yang telah memulai penelitian budaya keselamatan pasien, baik Negara maju maupun Negara berkembang seperti Indonesia.

\section{a. Rumah Sakit}

Rumah sakit sebagai organisasi badan usaha di bidang kesehatan mempunyai peranan penting dalam mewujudkan derajat kesehatan masyarakat secara optimal. Oleh karena itu, rumah sakit dituntut agar mampu mengelola kegiatan nya dengan mengutamakan pada tanggung jawab para profesional di bidang kesehatan, khususnya tenaga medis dan tenaga keperawatan dalam menjalankan tugas dan kewenangannya.

Rumah sakit dalam melaksanakan tujuan, fungsi dan perannya memerlukan Suatu bentuk pengaturan yang jelas. Banyak unsur-unsur yang terkandung di dalam penyelenggaraan Rumah Sakit terutama terkait dengan tugas utamanya dalam pelayanan publik yakni melakukan pelayanan kesehatan, maka membutuhkan perangkat hukum yang memadai. Hal itu dimaksudkan agar penyelenggaraannya sungguh-sungguh dapat sesuai dengan kedudukan, peran dan fungsinya, serta terutama untuk dapat memenuhi amanat konstitusi yaitu mewujudkan kesejahteraan masyarakat.

Pelayanan kesehatan adalah sebuah konsep yang digunakan dalam memberikan layanan kesehatan kepada masyarakat. Pelayanan kesehatan adalah setiap upaya yang diselenggarakan sendiri atau secara bersama-sama dalam suatu organisasi untuk memelihara dan meningkatkan kesehatan, mencegah dan menyembuhkan penyakit serta memulihkan kesehatan perorangan, keluarga kelompok dan masyarakat. Bentuk dan jenis dari pelayanan kesehatan ditentukan oleh:

a. Pengorganisasian pelayanan,apakah dilaksanakan secara sendiri atau secara bersama-sama dalam suatu organisasi.

b. Ruang lingkup kegiatan, apakah hanya mencakup kegiatan pemeliharaan kesehatan, pencegahan penyakit, penyembuhan penyakit, pemulihan kesehatan atau kombinasi daripadanya.

Keselamatan pasien adalah suatu sistem rumah sakit yang membuat asuhan pelayanan kesehatan pasien secara aman dengan pencegahan cidera terhadap pasien.

b. Keselamatan Pasien 
Keselamatan pasien adalah keselamatan pasien dan pencegahan, perbaikan dari kejadian yang tidak diharapkan atau mengatasi cidera dari proses pelayanan kesehatan. Tujuan dari keselamatan pasien telah ditentukan secara internasional maupun nasional dimana tujuan yang ditentukan secara internasional oleh Joint Commission Internasional (JCI) 2007 yaitu sebagai berikut:

a. Identify patient correctly (mengidentifikasi pasien dengan benar)

b. Improve effective communication (meningkatkan komunikasi yang efektif)

c. Improve the safety of high-alert medications(meningkatkan keamanan dari pengobatan risiko tinggi)

d. Eliminate wrong-site, wrong-patient, wrong procedure surgery (mengeliminasi kesalahan penempatan, kesalahan pengenalan pasien, kesalahan prosedur operasi)

e. Reduce the risk of health care-associated infections (mengurangi risiko infeksi yang berhubungan dengan pelayanan kesehatan)

f. Reduce the risk of patient harm from falls (mengurangi risiko pasien terluka karena jatuh)

Sedangkan tujuan keselamatan pasien menurut Departemen Kesehatan RI (2009), tujuan keselamatan pasien adalah sebagai berikut:

a. Tercapainya budaya keselamatan pasien di rumah sakit

b. Meningkatkan akuntabilitas rumah sakit terhadap pasien dan masyarakat

c. Menurunkan kejadian tidak diharapkan dirumah sakit

d. Terlaksananya program-program pencegahan sehingga tidak terjadi pengulangan kejadian tidak diharapkan

\section{c. Budaya Keselamatan Pasien}

Budaya keselamatan pasien adalah nilai, keyakinan, perilaku yang dianut individu dalam suatu organisasi mengenai keselamatan yang memprioritaskan dan mendukung peningkatan keselamatan. Budaya keselamatan pasien merupakan hal yang mendasar di dalam pelaksanaan keselamatan di suatu rumah sakit. Rumah sakit harus menjamin penerapan keselamatan pasien pada pelayanan kesehatan yang diberikannya kepada pasien.

Budaya keselamatan pasien adalah produk dari individu dan kelompok yang merupakan nilai dari sikap, persepsi, kompetensi dan perilaku yang menimbulkan komitmen 
dan pola dari suatu manajemen kesehatan mengenai keselamatan pasien. Organisasi dengan budaya keselamatan pasien yang positif mempunyai karakteristik komunikasi saling terbuka dan percaya ya serta persepsi yang sama mengenai pentingnya keselamatan pasien dan kenyamanan dalam pengukuran guna pencegahan.

Inti dari budaya keselamatan pasien adalah keyakinan karyawan tentang pentingnya keselamatan, yang ditunjukkan melalui sikap, norma-norma yang berlaku dan perilaku termasuk nilai-nilai yang menjadi asumsi dasar tentang bagaimana bertindak.

Tantangan terbesar yang perlu dilakukan dalam menciptakan budaya keselamatan pasien yang terbuka dalam mendirikan dan mempertahankan budaya positif tentang keselamatan pasien pada organisasi pelayanan kesehatan. Karakteristik budaya positif tentang keselamatan pasien diantaranya adalah persepsi yang diinformasikan tentang pentingnya keselamatan pasien, dan komitmen pemimpin serta tanggung jawab pembuat kebijakan. Salah satu tenaga yang berperan dalam usaha peningkatan budaya keselamatan pasien adalah perawat. Perawat melaksanakan tugas 24 jam dalam tujuh hari pelayanan langsung kepada pasien. Pelayanan yang diberikan berupa perawatan langsung dan pemeriksaan keadaan klinis pasien. Selain itu perawat juga melakukan koordinasi dan integrasi layanan perawatan lintas profesi dan unit.

Budaya keselamatan pasien yang baik dapat memperkecil insiden yang berhubungan dengan keselamatan pasien. Budaya keselamatan pasien adalah faktor penting dalam upaya untuk mengurangi risiko yang merugikan di rumah sakit dan meningkatkan keselamatan pasien.Untuk meningkatkan budaya keselamatan pasien, kesadaran perawat tentang pentingnya keselamatan pasien juga perlu ditingkatkan.

Pengukuran budaya keselamatan pasien perlu dilakukan oleh semua rumah sakit. Dengan survey budaya keselamatan pasien hasilnya akan membantu Rumah Sakit memahami kinerja rumah sakit saat ini, apa yang masih menjadi masalah dan perlu dilakukan perbaikan.

\section{Aspek Budaya Keselamatan Pasien}

O’Neal (2012) menilai budaya keselamatan pasien melalui tiga aspek:

1. Tingkat unit, mencakup: supervisor/manager action promoting safety, organizational learning-perbaikan berkelanjutan, kerjasama dalam unit 
di rumah sakit, komunikasi yang terbuka, umpan balik dan komunikasi mengenai kesalahan, respon tidak mempersalahkan terhadap kesalahan, dan manajemen ketenagakerjaan.

2. Tingkat rumah sakit, mencakup: dukungan manajemen terhadap upaya keselamatan pasien, kerjasama antar unit di rumah sakit, perpindahan transisi pasien

3. Keluaran, mencakup persepsi keseluruhan staf di rumah sakit terkait keselamatan pasien, frekuensi pelaporan kejadian, peringkat keselamatan pasien, jumlah total laporan kejadian dalam 12 bulan terakhir.

Budaya keselamatan pasien dapat ditegakkan pada beberapa hal, diantaranya:

1. Aktivitas organisasi yang berisiko tinggi dan kegiatan yang membutuhkan keamanan lebih

2. Lingkungan harus menyediakan suasana yang tidak menghakimi terhadap kesalahan yang dilakukan, sehingga kejadian terkait error atau near miss dapat dilaporkan untuk perbaikan tanpa adanya ketakutan tersendiri.

3. Kolaborasi dari semua pihak lintas sektoral dan kedisiplinan dapat menghasilkan solusi untuk menyelesaikan masalah keselamatan pasien.

4. Komitmen organisasi diperlukan untuk mendukung semua hal yang terkait dengan keselamatan pasien (Sorra et al. 2016).

\section{Karakteristik Budaya Keselamatan Pasien}

Terdapat beberapa karakteristik sebagai ciri jika suatu rumah sakit berkomitmen untuk menegakkan budaya keselamatan pasien (Commission, 2017), antara lain:

1. Pemimpin mendemonstrasikan komitmen untuk keselamatan dalam setiap keputusan dan perilakunya.

2. Keputusan pimpinan yang mendukung atau mempengaruhi keselamatan merupakan keputusan yang bersifat sistematis, kaku atau mengikat, dan penuh ketelitian.

3. Rasa saling percaya dan saling menghargai harus ditanamkan dalam suatu organisasi. 
4. Kesempatan untuk belajar mengenai cara mempertahankan keselamatan pasien terbuka lebar dan setelahnya akan diimplementasikan.

5. Isu-isu terkait yang berdampak pada keselamatan diidentifikasi secara tepat, dievaluasi secara menyeluruh, tepat sasaran dan sepadan dengan signifikansi tindakan yang dilakukan.

6. Lingkungan kerja yang aman dan penuh kesadaran terkait keselamatan yaitu lingkungan kerja di mana para personelnya merasa bebas untuk memperhatikan aspek keselamatan tanpa merasa terintimidasi, tanpa ada gangguan, diskriminasi dan ketakutan akan pembalasan.

7. Proses perencanaan dan aktivitas kontroling harus diimplementasikan sehingga keselamatan dapat dipertahankan.

Pemimpin dapat membangun budaya keselamatan pasien dengan kesiapan dan kemauan untuk berpartisipasi bersama anggota timnya, untuk berinisiatif.

\section{Dimensi Budaya Keselamatan Pasien}

Dimensi dalam budaya keselamatan pasien yaitu (Sorra et al. 2016):

1. Keterbukaan komunikasi

Staff merasa bebas untuk berbicara jika melihat sesuatu yang negatif yang berpengaruh terhadap pasien dan staff merasa bebas untuk bertanya lebih dalam dengan menggunakan otoritas yang mereka miliki.

2. Feedback dan komunikasi tentang kesalahan yang terjadi

Staff diinformasikan mengenai kesalahan yang terjadi, diberikan feedback mengenai perubahan yang akan diimplementasikan, dan mendiskusikan cara untuk mencegah kesalahan.

3. Frekuensi pelaporan kejadian Kesalahan yang dilaporkan yaitu dalam bentuk:

a. Kesalahan yang diketahui dan diperbaiki karena menyangkut pasien

b. Kesalahan yang tidak berpotensi membahayakan pasien

c. Kesalahan yang dapat membahayakan pasien

4. Handoff dan transisi

Pertukaran informasi mengenai perawatan pasien disebarkan antar unit dalam rumah sakit dan disebarkan ketika pergantian shift jaga. 
5. Dukungan organisasi untuk keselamatan pasien

Manajemen rumah sakit menyediakan lingkungan kerja yang mempromosikan keselamatan pasien dan menunjukkan bahwa keselamatan pasien merupakan prioritas dalam manajemen rumah sakit.

6. Nonpunitive respon to error/respon tidak menghakimi pada kesalahan yang dilakukan Staff merasa bahwa kesalahan dan kejadian yang dilaporkan tidak ditujukan untuk menyalahkan dirinya, dan kesalahan tersebut tidak hanya menjadi masalah pribadinya saja.

7. Organizational learning-pembelajaran berkelanjutan

Kesalahan akan mendorong perubahan positif dan perubahan tersebut akan dievaluasi untuk menilai keefektifannya.

8. Persepsi keseluruhan mengenai keselamatan pasien

Sistem dan prosedur yang ada sudah bagus untuk pencegahan kesalahan dan hanya terdapat sedikit masalah mengenai keselamatan pasien.

9. Staffing

Staff yang ada di rumah sakit sudah cukup untuk mengatasi beban kerja yang tinggi dan jam kerja sudah sesuai untuk melakukan perawatan dan pelayanan terbaik untuk pasien.

10. Supervisor/harapan manajer dan tindakan yang dilakukan untuk meningkatkan keselamatan pasien

Supervisor/manajer mempertimbangkan saran dari staff untuk meningkatkan keamanan pasien, memberikan respon positif terhadap staff yang mengikuti prosedur keselamatan pasien dengan benar dan tidak berlebihan dalam melakukan pembahasan mengenai masalah keselamatan pasien.

11. Kerjasama lintas unit

Unit-unit dalam rumah sakit bekerja sama dan berkordinasi satu sama lain untuk menyediakan pelayanan terbaik untuk pasien.

12. Kerjasama antar unit/dalam unit

Staff dalam unit saling mendukung satu sama lain, saling menghargai satu sama lain dan bekerja sama sebagai satu tim. 
Sammer et al. (2010) dalam penelitiannya membagi budaya keselamatan pasien ke dalam 7 sub, yaitu:

\section{Kepemimpinan}

Seorang pemimpin harus mengetahui bahwa lingkungan perawatan kesehatan merupakan lingkungan yang berisiko tinggi dan mencari kesamaan visi dan misi, mempertimbangkan kompetensi staff, masalah keuangan dan sumber daya yang dibutuhkan.

\section{Kerjasama tim}

Kerjasama tim dapat diwujudkan dalam bentuk menghargai kolega kerjanya, kolaborasi dan kerjasama yang terjadi antara staff, manajer dan praktisi independen lainnya. Hubungan yang dibangun bersifat terbuka, aman, saling menghargai dan fleksibel.

\section{Evidence-based}

Praktik pelayanan dan perawatan yang diberikan kepada pasien berdasarkan evidence based. Semua proses yang berhubungan dengan pelayanan dibuat untuk menghasilkan perawatan yang mempunyai reliabilitas tinggi. Standar dalam perawatan pasien diperlukan untuk mengurangi variasi dalam perawatan pasien, dan terdapat kesamaan dalam aspek-aspek perawatan pasien.

\section{Komunikasi}

Lingkungan pekerjaan di rumah sakit akan dapat mempertahankan keberadaannya jika semua staff apa pun jenis pekerjaannya, mempunyai hak dan tanggung jawab untuk mengeluarkan pendapat atau bersuara, mengenai segala sesuatu yang berkaitan dengan pasien.

\section{Pembelajaran}

Rumah sakit belajar dari kesalahan dan melihat kesempatan baru untuk meningkatkan kinerja. Proses pembelajaran merupakan hal yang penting untuk diaplikasikan oleh semua staff, tidak hanya staff medis.

\section{Just culture}

Budaya yang mengenali kesalahan sebagai suatu kegagalan sistem dibandingkan kesalahan individu akan membantu individu untuk bertanggung jawab terhadap perbuatannya dengan tidak merasa dihakimi oleh organisasinya.

\section{Patient-centered}


Pelayanan yang berfokus pada pasien merupakan pelayanan yang berfokus pada pasien dan keluarga pasien. Pasien bukan hanya harus berpartisipasi aktif dalam perawatannya, tetapi pasien juga merupakan penyambung antara rumah sakit dengan komunitas.

\section{8 (Delapan) Langkah untuk Mengembangkan Budaya Keselamatan Pasien(Hasting G., 2008)}

\section{Put the focus back on safety (kembali fokus ke keselamatan pasien)}

Setiap staf yang bekerja di Rumah Sakit pasti ingin memberikan yang terbaik dan teraman untuk pasien. Tetapi supaya keselamatan pasien ini bisa dikembangkan dan semua staf merasa mendapatkan dukungan, patient safety ini harus menjadi prioritas strategis dari rumah sakit atau unit pelayanan kesehatan lainnya. Empat CEO Rumah Sakit yang terlibat dalam safer patient Initiatives di Inggris mengatakan bahwa tanggung jawab untuk keselamatan pasien tidak bisa didelegasikan dan mereka memegang peran kunci dalam membangun dan mempertahankan fokus patient safety di dalam Rumah Sakit.

2. Think small and make the right thing easy to do (berpikir mudah dan membuat langkah mudah untuk peningkatan pelayanan)

Memberikan pelayanan kesehatan yang aman bagi pasien mungkin membutuhkan langkahlangkah yang agak kompleks. Tetapi dengan memecah kompleksitas ini dan membuat langkah-langkah yang lebih mudah mungkin akan memberikan peningkatan yang lebih nyata.

\section{Encourage open reporting (mendorong sistem pelaporan terbuka)}

Belajar dari pengalaman, meskipun itu sesuatu yang salah adalah pengalaman yang berharga. Koordinator patient safety dan manajer RS harus membuat budaya yang mendorong pelaporan. Mencatat tindakan-tindakan yang membahayakan pasien sama pentingnya dengan mencatat tindakan-tindakan yang menyelamatkan pasien. Diskusi terbuka mengenai insideninsiden yang terjadi bisa menjadi pembelajaran bagi semua staf.

\section{Make data capture a priority (membuat sistem pencatatan sebagai prioritas)}

Dibutuhkan sistem pencatatan data yang lebih baik untuk mempelajari dan mengikuti perkembangan kualitas dari waktu ke waktu. Misalnya saja data mortalitas. Dengan perubahan data mortalitas dari tahun ke tahun, klinisi dan manajer bisa melihat bagaimana manfaat dari penerapan patient safety. 
5. Use systems-wide approaches (gunakan pendekatan sistem yang menyeluruh bukan individual)

Keselamatan pasien tidak bisa menjadi tanggung jawab individual. Pengembangan hanya bisa terjadi jika ada sistem pendukung yang adekuat. Staf juga harus dilatih dan didorong untuk melakukan peningkatan kualitas pelayanan dan keselamatan terhadap pasien. Tetapi jika pendekatan patient safety tidak diintegrasikan secara utuh ke dalam sistem yang berlaku di RS, maka peningkatan yang terjadi hanya akan bersifat sementara.

6. Build implementation knowledge ( mengembangkan sistem berpikir dan implementasi program)

Staf juga membutuhkan motivasi dan dukungan untuk mengembangkan metodologi, sistem berpikir, dan implementasi program. Pemimpin sebagai pengarah jalannya program disini memegang peranan kunci. Di Inggris, pengembangan mutu pelayanan kesehatan dan keselamatan pasien sudah dimasukkan ke dalam kurikulum kedokteran dan keperawatan, sehingga diharapkan sesudah lulus kedua hal ini sudah menjadi bagian dalam budaya kerja.

\section{Involve patients in safety efforts (melibatkan pasien dalam usaha keselamatan)}

Keterlibatan pasien dalam pengembangan patient safety terbukti dapat memberikan pengaruh yang positif. Perannya saat ini mungkin masih kecil, tetapi akan terus berkembang.

Dimasukkannya perwakilan masyarakat umum dalam komite keselamatan pasien adalah salah satu bentuk kontribusi aktif dari masyarakat (pasien). Secara sederhana pasien bisa diarahkan untuk menjawab ketiga pertanyaan berikut: apa masalahnya? Apa yang bisa kubantu? Apa yang tidak boleh kukerjakan?

8. Develop top-class patient safety leaders (mengembangkan kepemimpinan keselamatan pasien yang berkualitas)

Prioritasi keselamatan pasien, pembangunan sistem untuk pengumpulan data-data berkualitas tinggi, mendorong budaya tidak saling menyalahkan, memotivasi staf, dan melibatkan pasien dalam lingkungan kerja bukanlah sesuatu hal yang bisa tercapai dalam semalam. Diperlukan kepemimpinan yang kuat, tim yang kompak, serta dedikasi dan komitmen yang tinggi untuk tercapainya tujuan pengembangan budaya patient safety. Sering kali RS harus bekerja dengan 
konsultan leadership untuk mengembangkan kerjasama tim dan keterampilan komunikasi staf.

Dengan kepemimpinan yang baik, masing-masing anggota tim dengan berbagai peran yang berbeda bisa saling melengkapi dengan anggota tim lainnya melalui kolaborasi yang erat.

\section{KESIMPULAN}

Keragaman dan keteraturan para pelayan kesehatan jika tidak dikelola dengan baik dapat terjadi insiden keselamatan pasien. Keselamatan pasien di rumah sakit melibatkan partisipasi dari semua petugas kesehatan, terutama perawat. Keselamatan pasien adalah prioritas utama dan harus segera dilaksanakan di rumah sakit karena dapat menyebabkan cedera langsung kepada pasien, terkait dengan kualitas dan nilai rumah sakit serta standar pelayanan yang harus dipenuhi oleh standar akreditasi Rumah Sakit terkait untuk versi 2012 yang telah mengacu pada Joint Commission Internasional (JCI).

Budaya keselamatan pasien adalah bagian dari kesalahan laten terkait dengan manajemen indikatornya adalah budaya keselamatan kerja sama, komunikasi, kepemimpinan, pelaporan dan respon tidak menghukum atas kesalahan. Inti dari budaya keselamatan pasien adalah keyakinan karyawan tentang pentingnya keselamatan, yang ditunjukkan melalui sikap, norma-norma yang berlaku dan perilaku termasuk nilai-nilai yang menjadi asumsi dasar tentang bagaimana bertindak.

Budaya keselamatan pasien yang baik dapat memperkecil insiden yang berhubungan dengan keselamatan pasien. Budaya keselamatan pasien adalah faktor penting dalam upaya untuk mengurangi risiko yang merugikan di rumah sakit dan meningkatkan keselamatan pasien. Untuk meningkatkan budaya keselamatan pasien, kesadaran perawat tentang pentingnya keselamatan pasien juga perlu ditingkatkan.

\section{DAFTAR PUSTAKA}

1. Arini, Tantri.2018.Budaya Keselamatan Pasien Berbasis Pemberdayaan Struktural Dengan Kepuasan Kerja Perawat.Tesis.Program Studi Magister Keperawatan Fakultas Keperawatan Universitas Airlangga. 
2. Buhari,Basok.2019.Budaya Keselamatan Pasien Rumah Sakit Pemerintah dan Rumah Sakit Swasta di Kota Jambi. Jurnal 'Aisyiyah Medika Vol 3 (1):1-18.

3. Fitriana,Yuni.,Kurniasari Pratiwi.2018.Pelaksanaan Patient Safety di Rumah Sakit Umum Daerah dan Rumah Sakit Umum Swasta Bantul Berdasarkan Ketentuan Undang-Undang Nomor 44 Tahun 2009 Tentang Rumah Sakit. Jurnal Kebidanan Vol $7(1): 28-39$.

4. Harus, Bernadeta Dece., Ani Sutriningsih.2015.Pengetahuan Perawat Tentang Keselamatan Pasien Dengan Pelaksanaan Prosedur Keselamatan Pasien Rumah Sakit (KPRS) di Rumah Sakit Panti Waluya Sawahan Malang.Jurnal Care Vol 3 (1): 25-32.

5. Hamzah.,Susmiati.,Emil Huriani.2019.Gambaran Budaya Keselamatan Profesional Pemberi Asuhan di Kamar Operasi. Jurnal Perawat Indonesia Vol 3 (2) : 139-144.

6. Herawati, Yennike Tri.,2015.Budaya Keselamatan Pasien di Ruang Rawat Inap Rumah Sakit X Kabupaten Jember. Jurnal IKESMA Vol 11 (1): 52-60.

7. Juniarti, Nanda Hani., Ahmad Ahid Mudayana.2018.Penerapan Standar Keselamatan Pasien di Rumah Sakit Umum Daerah Provinsi Nusa Tenggara Barat. Jurnal Kesehatan Poltekkes Ternate Vol 11(2): 93-108.

8. Kartika, Imelda Rahmayunia., Yelpio Stenalia.2019.Deskripsi Penerapan Patient Safety Pada Pasien di Bangsal Bedah. Jurnal Human Care Vol 4 (2): 86-94.

9. Mudayana, Ahmad Ahid.2014.Peran Aspek Etika Tenaga Medis Dalam Penerapan Budaya Keselamatan Pasien di Rumah Sakit.Supplemen Majalah Kedokteran Andalas Vol 37 (1): 69-74.

10. Mundakir., Yuanita Wulandari.,Nur Mukarromah.2016.Pendekatan Model Asuhan Keperawatan Holistik Sebagai Upaya Peningkatan Kepuasan dan Keselamatan Pasien di Rumah Sakit. Jurnal Keperawatan Muhammadiyah Vol 1(2): 7-16.

11. Najihah.2018.Budaya Keselamatan Pasien dan Insiden Keselamatan Pasien di Rumah Sakit : Literature Review. Journal of Islamic Nursing Vol 3(1):1-8.

12. Salawati, Liza.2020.Penerapan Keselamatan Pasien Rumah Sakit. Jurnal Averrous Vol 6 (1): 98-107.

13. Simamora, R. H. (2018). Buku ajar keselamatan pasien melalui timbang terima pasien berbasis komunikasi efektif: SBAR. Medan: USUpress.

14. Simamora, R. H. (2020). Learning of Patient Identification in Patient Safety Programs Through Clinical Preceptor Models. Medico Legal Update, 20(3), 553-556.

15. Siregar, Rospita A.2016.Hubungan Perawat dan Pasien : Implementasi Standar Keselamatan Pasien. Jurnal Hukum tô-râ Vol 2 (1):295-304. 
16. Suci, Wice Purwani.2018.Peningkatan Budaya Keselamatan Pasien Melalui Pemberdayaan Champion Keselamatan Pasien. JKH Vol 2(2): 23-39.

17. Syam, Nur Syarianingsih.2017.Implementasi Budaya Keselamatan Pasien Oleh Perawat di Rumah Sakit Ibnu Sina Makassar. Jurnal Fakultas Kesehatan Masyarakat Vol 11 (2):169-174

18. Triwibowo, Cecep., Sulhah Yuliawati., Nur Amri Husna.2016.Handover Sebagai Upaya Peningkatan Keselamatan Pasien (Patient Safety) di Rumah Sakit. Jurnal Keperawatan Soedirman Vol 11(2): 76-80.

19. Tutiany., Lindawati., Paula Krisanti.2017.Bahan Ajar Keperawatan : Manajemen Keselamatan Pasien.Kementrian Kesehatan Republik Indonesia:48-49.

20. Vellyana,Diny.2015.Analisis Budaya Keselamatan Pasien Dalam Pelayanan Kesehatan di RS PKU Muhammadiyah Unit II Gamping.Tesis.Program Studi Manajemen Rumah Sakit Program Pascasarjana Universitas Muhammadiyah Yogyakarta.

21. Yasmi, Yulia., Hasbullah Thabrany.2018.Faktor-Faktor yang Berhubungan dengan Budaya Keselamatan Pasien di Rumah Sakit Karya Bhakti Pratiwi Bogor Tahun 2015. Jurnal ARSI Vol 4(2): 98-109. 